\title{
MENILIK ULANG PERADABAN ISLAM Sebuah Kajian Nas danSejarah
}

\author{
Taufiqurrahman Kurniawan \\ taufiqtwin@gmail.com
}

\begin{abstract}
The history of the Arabs of the past has followed the teachings of Ismail As and Ibrahim As. The doctrine that contains worship, crowding only to Allah SWT. But it has been marred by his followers named 'Amr bin Luhay a leader of Banu Khuza'ah by adding to the teachings of Abraham. Along the course of history, there was an Islamic civilization, but many historians wrote when the historic event took place. Many kinds of opinions in determining the month of the fall of revelation is the month of early Rabiul. There is also a set month of Ramadan. Another class sets the first revelation in Rajab by conveying all sorts of arguments. There is an opinion about the date at which the revelation was revealed to the Prophet (s). Some opinions specify the seventh date, there are also on the seventeenth, there are opinions on the eighteenth, other opinions of the nineteenth and there are also opinions that set the date of twenty-one. But historians agreed on Monday when revelation was revealed to Prophet Muhammad SAW. The question is when will the first revelation be revealed and how is the method used to extract the truth? The basic approach used is with the approach bayani and burhani. Ie used historical data or history (verse, hadith and tarikh) which is data serve and astronomical data which is data burhani. The analysis is done by cross-confirmation between data bayani and burhani data. Having processed these data then found conclusion that data burhani (astronomy) in accordance with the data bayani (history or history) stating that Badr War happened on 19th of Ramadan and thus al-Quran revealed the first time that marked the birth of Islamic civilization is on the day Monday 19th Ramadan year 14 SH coincides with August 25, 609 M. So the age of Islamic civilization on Tuesday, 18th Ramadan $1438 \mathrm{H}$ just last, even reached the age of 1451 years kamariah and Wednesday, 19th Ramadan 1438 H is his birthday- 1451. Keywords: civilization, Islam, revelation, history, ministry, burhani, birthday.
\end{abstract}

\section{A. Pendahuluan}

Bangsa Arab masa lampau adalah bangsa yang mengikuti ajaran atas dakwahnya Ismail As, yakni ketika 
beliau menyeru kepada agama bapaknya (Ibrahim As). Ajaran yang diserukan adalah berisi penyembahan kepada Allah SWT. Mengesakan-Nya dan memeluk agama-Nya. Seiring berkembangnya zaman, ajaran agama yang telah dibawa Ibrahim mulai disimpangkan oleh para pengikutnya.

Salah satu pengikut Ibrahim yang bernama 'Amr bin Luhay dan seorang pemimpin Bani Khuza'ah, masyarakat saat itu memuliakan dan menganggap sebagai sosok yang rajin ibadah serta dermawan bahkan sampai disebut sebagai wali dan seorang ulama besar waktu itu, datang setelah berkunjung ke Syam dengan membawa ajaran baru yang dianggapnya lebih sempurna daripada ajaran Ibrahim As. Dengan datangnya ajaran baru tersebut, ajaran murni Ibrahim telah mengalami banyak perubahan dan bahkan ditambahkan dengan cara-cara penyembahan yang lain sesuai dengan ajaran jahiliyah Syam. Sehingga ajaran Ibrahim menjadi rusak, para pengikutnya mengalami perubahan kultur yang banyak dipengaruhi oleh budaya Syam, bahkan tidak hanya itu, tidak sedikit yang mengalami pergeseran moral sehingga etika, ahlak masyarakat zaman itu menjadi tidak beradab, bejat dan sesat.

Pada bulan Ramadan pada tahun ketiga dari uzlahnya Nabi SAW di Gua Hira', Allah SWT telah melimpahkan rahmat-Nya kepada penghuni bumi, memuliakan sosok Nabi yang sangat arif dan bijaksana yakni Muhammad SAW dengan nubuwah yang telah diberikan oleh Allah SWT dan menurunkan Jibril As kepada beliau dengan membawa ajaran Islam.

Islam muncul dari sebuah peradaban Arab yang banyak kultur yang diwarnai aneka budaya yang cukup kaya. Namun budaya itu belum diatur dengan aturan atau norma yang beradab, perilaku dan moral bangsa Arab sangat memprihatinkan. Ajaran Islam diturunkan oleh Allah SWT dengan tujuan menyempurnakan ahlak dan budi pekerti manusia yang sempurna.Sehingga bangsa Arab waktu itu menjadi bangsa yang mempunyai peradaban yang cukup tinggi dengan bekal ahlakul karimah.

Sejarah telah diukir dengan hadirnya peradaban Islam, namun banyak para ahli sejarah menulis kapan peristiwa bersejarah itu terjadi. Ada banyak perbedaan pendapat yang cukup tajam di antara para ahli sejarah dalam menetapkan 
awal bulan saat Allah mengangkat Muhammad menjadi Nabi dan menurunkan wahyu kepada beliau.

Pendapat yang paling banyak dalam menetapkan bulan turunnya wahyuadalah bulan Rabiul awal. Ada juga penetapan bulan saat kenabian adalah bulan Ramadan. Golongan lain menetapkan wahyu pertama pada bulan Rajab.Syaikh Abdullah bin Muhammad bin Abdul Wahhab An-Najdy berpendapat bahwa beliau lebih sepakat bahwa wahyu pertama itu turun pada bulan Ramadan. Hal ini dikuatkan firman Allah dalam surat Al-Baqarah ayat 185 . "Bulan Ramadan, bulan yang di dalamnya diturunkan (permulaan) Al Qur'an..." (QS: Al-Baqarah: 185). Di dalam surat Al-Qadar:1, "Sesungguhnya Kami telah menurunkannya (Al Qur'an) pada malam kemuliaan." Dan ada di dalam surat ad-Dukhan: 3, "sesungguhnya Kami menurunkannya pada suatu malam yang diberkahi,". Landasan ini yang dijadikan alasan bahwa wahyu pertama kali diturunkan kepada Nabi SAW adalah di bulan Ramadan.(Abdullah bin Muhammad bin Abdul Wahhab An-Najdy:75)

Pendapat lain mengenai hari apa wahyu diturunkan kepada Nabi SAW, namun tentang bulan, disepakati pada bulan Ramadan. Ada pendapat bahwa wahyu diturunkan pada hari ke tujuh, ada juga pada hari ke tujuh belas, ada pendapat pada hari ke delapan belas. Adapun pendapat AlKhudhry,menurutnya pada hari ke tujuh belas lebih kuat.(Rahmah Lil 'alamin, 1/49 dan Mukhtashar SiratirRasul, hal. 75).

Menurut pendapat Al-Mubarakfury bahwa pada waktu diturunkannya wahyu adalah pada hari ke dua puluh satu, sebab para ahli biografi sepakat bahwa wahyu turun itu hari tersebut, alasan yang mereka jadikan dasar adalah bahwa hari tersebut jatuh pada hari Senin. (Syafuyurrahman Al-Mubarakfury, 2007:44).

Hal ini didasarkan hadis Nabi SAW yang diriwayatkan dari Abū Qatādah bahwa ia berkata: "Rasulullah saw pernah ditanya tentang puasa hari Senin. Beliau menjawab: Itu adalah hari aku dilahirkan dan hari wahyu (pertama) diturunkan kepadaku." Argumentasi ini belum dianalisis lebih mendalam karena belum didampingi 
dengan argumentasi secara astronomis dengan metode burhani.

Sedikit tentu kita bertanya kapankah persisnya wahyu pertama itu diturunkan dan bagaimana metode yang dipakai dalam penyelidikan? Pendekatannya didasarkan kepada pendekatan bayani dan burhani. Untuk itu digunakan data-data riwayat (ayat, hadis dan tarikh) yang merupakan data bayani dan data astronomis yang merupakan data burhani. Analisis dilakukan dengan cara konfirmasi silang antara data bayani dan data burhani.

\section{B. Pembahasan}

Pada hari Rabu 19 Ramadan 1438 H / 14 Juni 2017 M yang baru lalu, adalah hari ulang tahun agama dan peradaban Islam yang ke-1451 menurut perhitungan tahun kamariah. Hari tersebut adalah hari lahirnya agama dan peradaban Islam 1451 tahun kamariah yang lalu ketika pertama kali al-Quran diwahyukan dan Muhammad saw ditahbiskan menjadi Rasul. berikut:

Dari beberapa data bayani ditemukan fakta sebagai

1. Bahwa wahyu pertama kali diterima oleh Nabi saw adalah pada hari Senin. Hal ini dinyatakan dalam sejumlah riwayat hadis, antara lain hadis,

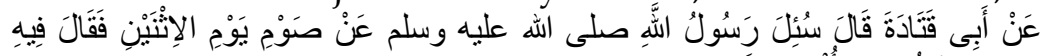

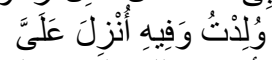

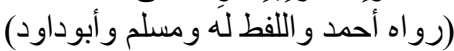

Dari Abū Qatādah [diriwayatkan bahwa] ia berkata: Rasulullah saw pernah ditanya tentang puasa hari Senin. Beliau menjawab: Itu adalah hari aku dilahirkan dan hari wahyu [pertama] diturunkan kepadaku (HR. Muslim, 1/368, Ahmad, 5/299, AlBaihaqy, 4/286-300, Al-Hakim, 2/602).

2. Bahwa wahyu pertama diturunkan itu adalah di malam hari. Hal ini ditegaskan dalam firman Allah surat ad-Dukhan ayat 3,

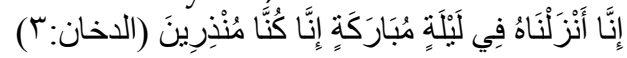

"Sesungguhnya Kami menurunkannya pada suatu malam yang diberkahi dan sesungguhnya Kamilah yang memberi peringatan" (Qs. Ad Dukhan: 3). Malam diturunkannya al-Quran pertama itu 
disebut Malam Qadar (Malam Kemuliaan). Ini ditegaskan dalam firman Allah,

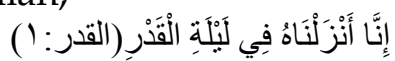

"Sesungguhnya Kami menurunkannya pada Malam Qadar (QS. Al Qadr: 1).Jadi al-Quran diturunkan pertama kali adalah pada malam Senin.

3. Bahwa wahyu al-Quran pertama kali diturunkan itu adalah di bulan Ramadan. Hal ini didasarkan kepada penegasan al-Quran sendiri dalam surat al-Baqarah ayat 185 ,

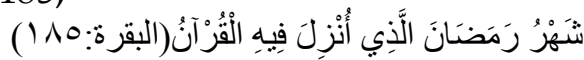

"(Hari-hari tertentu itu adalah) bulan Ramadan yang padanya al-Quran diturunkan ..." (QS. AL Baqarah: 185).

Hanya saja tidak ada keterangan yang tegas pada tanggal berapa al-Quran itu diturunkan di bulan Ramadan. Tetapi terdapat dua data yang dapat memberikan gambaran awal sebagai berikut,

1. Bahwa al-Quran diturunkan pada hari yang disebut Hari Pemisahan, yaitu hari terjadinya kontak senjata antara dua pasukan. Hal ini disebutkan dalam al-Quran surat al-Anfal ayat 41, firman Allah:

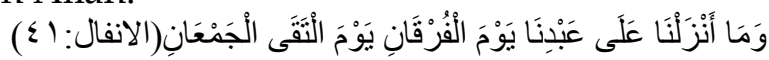
“... ... ... dan apa yang Kami turunkan (alQuran) kepada hamba Kami pada Hari Pemisahan, yaitu hari bertemunya dua pasukan" (QS. Al Anfal: 41).

2. Data sejumlah riwayat hadis menyebutkan bahwa Hari Pemisahan, yang merupakan hari bertemunya dua pasukan itu, adalah hari terjadinya Perang Badar. Ini disebutkan antara lain dalam riwayat al-Ḥākim,

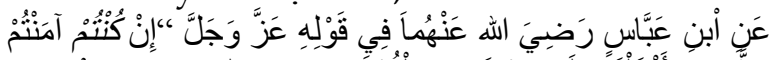

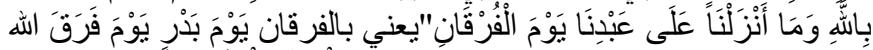

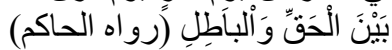

Dari Ibn 'Abbās r.a. mengenai firman Allah "dan apa yang Kami turunkan (al-Quran) kepada hamba Kami pada Hari Pemisahan, yaitu hari bertemunya dua pasukan" (diriwayatkan bahwa) yang dimaksud dengan Hari Pemisahan adalah hari Perang Badar, yang merupakan hari Allah memisahkan antara yang hak 
dan yang batil (HR al-Ḥākim. Ia dan aż-Żahabī menyatakannya sahih).

Berdasarkan hadis di atas dan sejumlah riwayat lainnya para ahli tafsir menafsirkan Hari Pemisahan, yaitu hari bertemunya dua pasukan itu, sebagai hari (tanggal) terjadinya Perang Badar. Demikian ditegaskan oleh atȚabarī, Ibn Kas̀īr, al-Qurțubī dan beberapa ahli tafsir lainnya yang menyebutkan tanggal yang berbeda antara lain 17, 18, 19, 21 dan 24 Ramadan. Dengan demikian al-Quran turun pertama kali pada malam Senin di bulan Ramadan pada tanggal yang sama dengan tanggal terjadinya Perang Badar.

Begitu pula lama Nabi SAW tinggal di Makkah sejak wahyu pertama diturunkan ini merupakan awal pelacakan tahun pertama kali diturunkan Al-Qur'an. Hal ini terdapat tiga versi riwayat yang sama-sama riwayat hadis sahih, yaitu,

1. Riwayat yang menegaskan 10 tahun. Ini terdapat dalam hadis Anas Ibn Mālik,

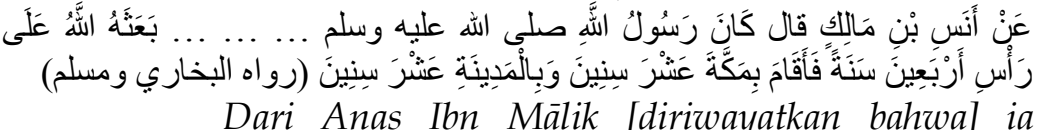

berkata: Adalah Rasulullah saw ... ... ... diutus oleh Allah ketika berusia 40 tahun dan beliau tinggal di Mekah 10 tahun dan di Madinah 10 tahun (HR al-Bukhārī dan Muslim).

2. Riwayat yang menyatakan 13 tahun. Ini terdapat dalam beberapa hadis, antara lain,

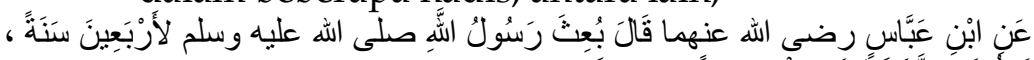

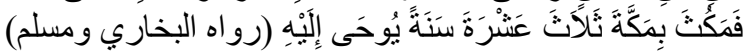

Dari Ibn 'Abbās (diriwayatkan bahwa) beliau berkata: Rasulullah saw diutus (menjadi Nabi saw) ketika berusia 40 tahun, dan beliau berada di Mekah selama 13 tahun menerima wahyu (HR al-Bukhārī dan Muslim).

3. Riwayat yang menyatakan 15 tahun. Ini terdapat dalam hadis,

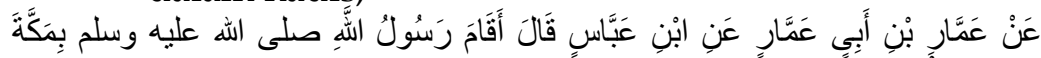

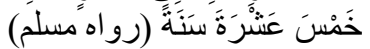

Dari 'Ammār, dari Ibn 'Abbās (diriwayatkan bahwa) ia berkata: Rasulullah saw bermukim di Mekah 15 tahun (HR Muslim). Maksudnya Rasulullah saw bermukim di Mekah 15 tahun sejak menerima wahyu pertama hingga hijrah ke Madinah. 
Para ulama menegaskan bahwa riwayat 13 tahun lebih sahih. Ibn Kasīir menyatakan bahwa riwayat yang paling masyhur adalah yang menyatakan 13 tahun. Ibn Hajar menyatakan bahwa riwayat 13 tahun (riwayat kedua) lebih sahih dari riwayat 10 tahun (riwayat pertama) dan riwayat 15 tahun (riwayat ketiga). An-Nawawī dan al-Mubārakfūrī menegaskan, "Pendapat yang benar adalah 13 tahun." Itu berarti bahwa beliau menerima wahyu pertama hingga berhijrah ke Madinah adalah tahun $14 \mathrm{SH}$. Aț-Ṭabarī menyatakan bahwa Nabi saw berada di Mekah selama 13 tahun penuh lebih beberapa bulan tepatnya selama 13 tahun 5 bulan 22 hari. Sehingga beliau berhijrah pada tahun ke-14 dari kenabiannya. Dengan demikian dapat ditegaskan bahwa wahyu al-Quran pertama diturunkan kepada Nabi saw adalah pada malam Senin 19 Ramadan tahun $14 \mathrm{SH}$ yang bertepatan dengan tanggal 25 Agustus $609 \mathrm{M}$.

Analisis data burhani telah ditemukan bahwa, Ijtima atau konjungsi jelang Ramadan tahun $14 \mathrm{SH}$ terjadi pada hari Selasa, 05 Agustus 609 M pukul 14:30:41 Waktu Mekah. Tinggi toposentrik titik pusat bulan saat itu adalah $02^{\circ} 06^{\prime}$ $03^{\prime \prime}$ dan elongasi toposentrik $+04^{\circ} 01^{\prime} 44^{\prime \prime}$. Posisi geometris seperti ini menurut kriteria mana pun (kesepakatan Istanbul 1978) belum memungkinkan hilal untuk terlihat dengan mata telanjang. Oleh karena itu tanggal 1 Ramadan tahun 14 SH jatuh pada hari Kamis 07 Agustus 609 M. Tanggal 17 Ramadan tahun 14 SH jatuh pada hari Sabtu, 23 Agustus 609 M. Tanggal 19 Ramadan $14 \mathrm{SH}$ jatuh pada hari Senin, bertepatan tanggal 25 Agustus $609 \mathrm{M}$.

\section{Kesimpulan}

Telah dapat disimpulkan bahwa data astronomi sesuai dengan sejarah atau riwayat yang menyatakan bahwa Perang Badar terjadi tanggal 19 Ramadan dan dengan demikian al-Quran diwahyukan pertama kali yang menandai lahirnya peradaban Islam adalah pada hari Senin 19 Ramadan tahun 14 SH. Jadi riwayat yang menyatakan bahwa Perang Badar dan wahyu pertama diturunkan terjadi pada tanggal 17 Ramadan tidak sesuai oleh data astronomi karena menurut data astronomi tanggal 17 Ramadan tahun $14 \mathrm{SH}$ adalah hari Sabtu, sementara Nabi saw menerima wahyu pertama adalah hari Senin. Dengan menghitung sejak hari Senin tanggal 19 Ramadan tahun 14 SH, maka usia 
peradaban Islam pada hari Selasa, 18 Ramadan $1438 \mathrm{H}$ baru lalu, genap mencapai usia 1451 tahun kamariah dan hari Rabu, 19 Ramadan $1438 \mathrm{H}$ adalah hari ulang tahunnya yang ke-1451.

\section{Daftar Pustaka}

Depag RI, Al-Qur'an dan Tafsirnya, jilid I, cet. I, (Jakarta: Yayasan Penyelenggaraan Penterjemah/Pentafsiran Al-Qur'an, 1975).

Syamsul Anwar," Kalender Hijriah Global Penyatuan jatuhnya Hari Arafah," makalah disampaikan pada "Halaqah Nasional Ahli Hisab dan Ahli Fikih Muhammadiyah," diselenggarakan di Yogyakarta pada tanggal 14 - 15 Zulkaidah 1435 H/ 9 -10 September 2014 M.

Syamsul Anwar, Metode Usul Fiqh Untuk Kontekstualisasi Pemahaman Hadis-Hadis Rukyat, "Jurnal tarjih dan tajdid, vol 11 (1) (1434/2013).

Syamsul Anwar, Interkoneksi Studi Hadis dan Astronomi, (Yogyakarta: SuaraMuhammadiyah, $2011 \mathrm{M}$ ).

Syaraf al-Qudah, "Isbatasy-Syahr al-Qamaribaina al-Hadis an-Nabawiwa al-'Ilm al-Hadis, "makalah disajikan dalam Mu'tamar al-Imarat al-Falaki al-Awwal (Muktamar Astronomi Pertama Emirat), 13-14 Desember 2006.

Syafuyurrahman Al-Mubarak fury, Ar-Rakhiqul Mahtum, (Bairut: Dar Al-Kutb Al-Ilmiyyah, 1428 H/2007 M). Shahih Bukhari, Muslim, 1/368, Ahmad, 5/299, Al-Baihaqy, 4/286-300, Al-Hakim, 2/602. 